\title{
Gambaran Negative Automatic Thoughts pada Remaja Korban Bullying di Sekolah Menengah Pertama Kota Bandung
}

\author{
Andhita Nurul Khasanah, Temi Damayanti, Dwi Agustin Nuriani Sirodj \\ Universitas Islam Bandung, Jalan Tamansari No.1, Bandung \\ e-mail: andhitanurul@yahoo.com
}

\begin{abstract}
This research aimed to obtain a description explanation about negative automatic thoughts that appear on Bandung junior high school students who are bullied. The research also described the automatic negative thoughts that was based on factors affected by bullying (from CATS questionnaire). The research involved 1261 samples of the students of 5 junior high school in Bandung. Data were analyzed using descriptive statistic analysis. The results showed as many as 48 students belonging to students who experience the action of bullying with high frequency and as many as 333 students experience the act of bullying in the medium frequency. Then, based on the results of CATS questionnaires, about $8.3 \%$ of students, show that they had higher frequency the occurrence of negative automatic thoughts. It means they had a negative beliefs scheme and often experience helplessness in their daily lives. The factor analysis showed that social threat was the most contributive factor in generating negative automatic thoughts.
\end{abstract}

Keywords: bullying, negative automatic thoughts, CATS, adolescent

\begin{abstract}
Abstrak
Penelitian ini bertujuan untuk memperoleh gambaran mengenai pikiran otomatis negatif yang muncul pada remaja korban bullying siswa SMP di Kota Bandung. Penelitian ini juga bertujuan untuk memetakan pikiran negatif otomatis tersebut berdasarkan kelompok faktor-faktor atau area mana (berdasarkan kuesioner CATS) yang paling sering terkena dampak akibat bullying. Penelitian melibatkan total sampel 1261 siswa SMP di 5 Sekolah. Data dianalisis menggunakan analisis statistik deskriptif. Hasil penelitian menunjukkan sebanyak 48 siswa tergolong pada siswa yang mengalami tindakan bullying dengan frekuensi tinggi dan sebanyak 333 siswa mengalami tindakan bullying dalam frekuensi sedang. Kemudian, berdasarkan hasil kuesioner CATS, sebanyak 8,3\% siswa, menunjukkan bahwa mereka mengalami frekuensi kemunculan negative automatic thoughts yang tinggi. Hal ini berarti mereka memiliki skema beliefs yang negatif dan sering mengalami ketidakberdayaan dalam kehidupan sehari-harinya. Berdasarkan analisa faktor kuesioner CATS, diperoleh hasil bahwa social threat menjadi faktor yang paling berkontribusi dalam memunculkan negative automatic thoughts.
\end{abstract}

Kata Kunci: bullying, negative automatic thoughts, CATS, remaja

\section{Pendahuluan}

Perilaku bullying merupakan salah satu perilaku agresif yang di dalamnya memiliki aspek kesengajaan untuk mendominasi, menyakiti, atau menyingkirkan. Di dalamnya juga terdapat ketidakseimbangan kekuatan fisik maupun mental, keterampilan, status sosial, dan kemampuan kognitif, dimana perilaku agresif ini dilakukan secara berulangkali oleh seseorang atau sekelompok orang kepada anak atau beberapa anak yang lainnya (Olweus, 1993; Sheras dan Tippins, 2002; Gini,
2004; Pereira, Mendonça, Neto, Valente dan Smith, 2004; Veenstra, Lindenberg, De Winter, Oldehinkel, Verhulst dan Ormel, 2005; Bauman dan Del Rio, 2006; Black dan Jackson, 2007, dalam Saptandari dan Adiyanti, 2013).

Menurut beberapa kajian penelitian, prevalensi paling besar munculnya tindakan bullying adalah pada usia sekolah menengah pertama atau usia 12-18 tahun. Mereka yang menjadi korban bullying umumnya adalah remaja yang memiliki kesulitan atau tidak mampu berhubungan 
dengan kelompok teman sebayanya bila dibandingkan dengan remaja pada umumnya (Pelligrini dan Long, 2002, dalam McMannis, 2012).

Pada faktanya, umumnya para korban bullying ini enggan untuk mengadukan apa yang mereka alami kepada orang lain, termasuk guru. Keengganan murid untuk melaporkan bullying yang dialaminya kepada guru mungkin disebabkan rasa percaya murid yang kurang terhadap guru (Soedjatmiko, Soedjatmiko, Nurhamzah, Waldi, Maureen, Anastasia, Wiguna dan Tjhin, 2013). Mereka menilai bahwa guru kurang responsif dan menganggap bahwa masalah yang dihadapi siswa bukanlah masalah besar. Selain itu, keengganan untuk menceritakan kejadian yang mereka alami juga disebabkan adanya kekhawatiran baik dalam jangka panjang maupun pendek dari para korban, jika mereka mengadukan apa yang dialami. Tuduhan sebagai "pengadu" bisa kembali memperparah tindakan bullying berikutnya. Selain kekhawatiran jika mengadukan permasalahan yang dihadapi, korban bullying juga akan menghadapi dampak lainnya secara psikososial. Korban bullying seringkali menjadi depresi, cemas, melakukan tindakan ke arah menyakiti diri sendiri, eating disoders, dan gejala-gejala masalah fisik seperti sakit kepala, sakit perut, demam, dan sulit tidur (Buxton, Potter dan Bostic, 2013).

Pelabelan dan tindakan negatif yang diterima oleh korban adalah hal yang sering mereka alami. Bagi mereka yang mengalami bullying dan diberikan label tertentu setiap kali melakukan interaksi dengan para pelaku, memunculkan persepsi negatif mengenai diri (Crick dan Bigbee, 1998; Prinstein dkk., 2001; Owens dkk., 2000; Vernberg, 1990; dalam Wang, 2011). Ia juga menjelaskan dalam penelitiannya bahwa pengalaman akan kekerasan pada remaja ini dapat menguatkan negative belief mengenai diri mereka. Keyakinan diri yang negatif ini muncul melalui negative automatic thoughts sebagai 'lapisan' terluar dari struktur kognitif seseorang. Pikiran-pikiran negatif ini dapat kita lihat frekuensi kemunculannya. Semakin sering ia muncul, maka akan semakin besar pula pengaruhnya pada pembentukan belief seorang remaja.

Negative automatic thoughts (NATs) sendiri adalah aliran pikiran dimana hampir semua dari kita menyadari akan kehadirannya dan berusaha memperhatikannya. Negative autmatic thoughts ini berbentuk pikiran negatif yang bernuansa pesimis dan memiliki penilaian atau interpretasi yang bernuansa negatif mengenai kejadian-kejadian yang terjadi di sekitar kita (Westbrook, dkk., 2007, dalam Khasanah, 2014). Negative automatic thoughts atau pikiran-pikiran negatif otomatis, secara langsung akan memengaruhi mood pada setiap kejadian dan sifatnya sangat cepat muncul serta seringkali kita sadari. Karena ini disadari, maka setiap orang bisa mempelajari cara untuk memantau kehadiran pikiran negatif tersebut (Westbrook dkk., 2007, dalam Khasanah, 2014). Negative automatic thoughts (NATs) ini sering membuat seseorang merasa tidak berdaya dan mengeluarkan coping yang tidak tepat (Wilding dan Milne, 2010; Khasanah, 2014). Jika coping tidak tepat, sulit bagi remaja untuk bisa bertahan dan menyikapi masalah yang ia hadapi dengan baik.

Frekuensi kemunculan negative automatic thoughts ini menjadi penting untuk diteliti karena kemunculan negative automatic thoughts membuat sebuah 'lingkaran setan' dalam diri mereka. Negative autmatic thoughts membuat mereka menilai bahwa situasi apapun yang ada kaitannya dengan pelaku, tempat terjadinya tindakan bullying, kalimatkalimat, perilaku, dan sebagainya, adalah hal yang tidak menyenangkan. Dengan begitu, mereka seringkali tidak pernah berhasil mengatasi rasa takut dalam dirinya agar bisa melakukan perlawanan terhadap para pelaku. Kondisi ini kemudian akan membuat para korban bullying semakin 
tidak berdaya menghadapi situasi yang mereka alami ini dan kemudian lambat laun akan memengaruhi skema belief pada diri mereka.

Berdasarkan kajian teori, skema belief bernuansa negatif akan semakin memengaruhi pembentukan jati diri dan keyakinan terhadap dirinya baik di masa sekarang maupun di masa mendatang. Skema ini kemudian memengaruhi sikap remaja dalam menghadapi situasi sosial, dimana mereka cenderung menghindar atau melarikan diri dari masalah yang dihadapi. Sehingga, keberadaan negative autmatic thoughts hanya akan membentuk 'vicious circle' pada remaja korban bullying.

Sejalan dengan riset yang telah dilakukan Khasanah (2014), bahwa remaja yang memiliki negative autmatic thoughts akan cenderung menghindari situasi bullying atau hal-hal yang terkait dengan pengalamannya. Misalnya, menghindari berpapasan dengan pelaku, menghindari tempat para pelaku berkumpul, menghindari percakapan dengan mereka, bahkan memiliki keinginan untuk tidak masuk sekolah.

Berdasarkan gambaran tinjauan yang telah dipaparkan, diharapkan penelitian ini dapat memetakan area-area psikososial mana yang paling sering memunculkan pikiran-pikiran otomatis bernuansa negatif pada remaja yang mengalami bullying. Dengan mengetahui seberapa tinggi pikiran-pikiran negatif tersebut muncul pada diri remaja, maka diharapkan peneliti dapat menambah khasanah pengetahuan mengenai dampak jangka panjang yang dialami oleh korban bullying terkait sistem belief mereka yang terrepresentasikan melalui negative automatic thoughts ini. Kemudian, data yang diperoleh terkait area psikososial dan frekuensi negative automatic thoughts ini, maka selanjutnya dapat disusun bentuk intervensi atau penanganan berdasarkan hasil riset ini.

Oleh karena itu, peneliti tertarik untuk melakukan survey secara menyeluruh mengenai pikiran-pikiran negatif yang muncul pada remaja korban bullying di tingkat sekolah menengah pertama. Kemudian peneliti juga tertarik untuk bisa memetakan pikiran-pikiran negatif otomatis tersebut berdasarkan pada area psikososial mana yang paling tinggi frekuensi kemunculannya.

\section{Bullying}

Menurut Olweus (1993; Rigby, dalam Khasanah, 2014) seorang siswa dapat dikatakan di-bully (digertak) atau disakiti ketika secara terang-terangan, berulangkali dan lebih dari sekali, mengalami perilaku negatif dari satu atau lebih siswa yang lainnya. Definisi ini secara jelas ditekankan pada perilaku negatif atau agresif yang dilakukan berulang dan lebih dari satu kali. Lebih spesifik lagi bahwa pada bullying terdapat ketidakseimbangan dalam kekuatan. Siswa yang secara terangterangan diperlakukan dengan negatif mengalami kesulitan untuk membela dirinya.

Menurut Mellor (dalam Asri, 2012) dari Antibullying Network University of Edinburgh, bullying terjadi ketika seseorang merasa teraniaya oleh tindakan orang lain baik yang berupa verbal, fisik, maupun mental, dan orang tersebut takut bila perilaku tersebut akan terjadi lagi. Sementara menurut Coloroso (dalam Asri, 2012) bullying adalah sebuah aktivitas sadar dan disengaja yang dimaksudkan untuk melukai, menanamkan ketakutan melalui ancaman agresi, dan menciptakan teror.

Sedangkan bullying yang terjadi di sekolah (school bullying) oleh Coloroso, 2004, dalam Asri, 2012) didefinisikan sebagai perilaku agresif yang dilakukan berulang-ulang oleh seorang/ sekelompok siswa yang memiliki kekuasaan, terhadap siswa lain yang lebih lemah, dengan tujuan menyakiti orang tersebut.

\section{Negative Automatic Thougths}

Negative automatic thoughts memengaruhi mood dan kemampuan coping 
seseorang, negative automatic thoughts ini kemudian memengaruhi mekanisme dalam pikiran korban bullying. Hal ini terjadi secara terus-menerus karena seringnya frekuensi tindakan bullying dialami oleh korban. Menurut kajian teori, apabila keyakinan atau belief seorang remaja terbentuk dalam nuansa negatif, maka hal ini tentu akan semakin memengaruhi pembentukan jati diri dan keyakinannya terhadap dirinya baik di masa sekarang maupun di masa mendatang.

Automatic thoughts adalah aliran pikiran dimana ia berada berdampingan dengan banyak kumpulan aliran pikiran (Beck, 1964, dalam Khasanah, 2014). Kita sering sedikit menyadari adanya pikiranpikiran ini. Ketika kita menjadi lebih menyadari pikiran-pikiran tersebut, maka secara otomatis kita akan melakukan reality check. Reality check ini berguna untuk mengetahui apakah kita sedang berada dalam masalah psikologis atau tidak yang dapat terlihat dari bentuk pikiran otomatis kita sendiri (Beck, 1964, dalam Khasanah, 2014).

Pikiran-pikiran otomatis ini tidak lepas dari core beliefs yang ada pada setiap individu. Core beliefs atau skema, disebut juga sebagai 'early maladaptive schema' atau skema awal yang maladaptif, berhubungan dengan inti dari perasaan-perasaan dari keburukan kita atau ketidakberhargaan, tidak dicintai, kurangnya kepercayaan terhadap diri sendiri atau orang lain, dan kurangnya kontrol terhadap hidup (Beck dkk., 1990; Layden dkk., 1993; Young dan Klosko, 1993; Young dan Behary, 1998, dalam Sanders dan Wills, 2003).

Ciri-ciri umum dari pikiran-pikiran yang negatif antara lain; (1) Pikiran-pikiran negatif muncul tiba-tiba dalam pikiran tanpa membutuhkan usaha sama sekali. (2) Pikiran-pikiran negatif mudah sekali untuk dipercaya. (3) Pikiran-pikiran negatif biasanya tidak benar. (4) Pikiran-pikiran negatif seringkali sulit untuk dihentikan. (5) Pikiran-pikiran negatif tidak membantu sama sekali. (6) Pikiran-pikiran negatif mempertahan-kan kita untuk tetap merasa khawatir dan tertekan, sehingga pikiranpikiran ini menjadi sangat sulit untuk diubah.

\section{Metode Penelitian}

Penelitian dilakukan dalam rangka memperoleh gambaran mengenai pikiranpikiran negatif yang seringkali muncul pada remaja korban bullying. Penelitian ini juga akan memetakan pikiran-pikiran negatif otomatis ini berdasarkan kelompok faktor-faktor atau area mana saja secara psikososial yang paling sering memunculkan pikiran-pikiran negatif terkait pengalaman bullying berdasarkan kuesioner yang dibuat oleh Schniering dan Rapee dari Macquire University. Metode yang digunakan adalah metode deskriptif berbentuk survey di lapangan untuk memperoleh data yang diperlukan. Hasil data ini kemudian diolah berdasarkan analisa statistika deskriptif (McMillan, 2006).

Populasi penelitian ini adalah siswa kelas VII dan VIII di seluruh SMP Negeri di Kota Bandung. Disebabkan adanya keterbatasan biaya, sumber daya, waktu, dan kesulitan dalam mengidentifikasi bahwa siswa yang mendapat perlakuan bullying akan terbuka maka metode sampling yang digunakan yaitu convenience sampling. Hal ini didasarkan pada convenience sample terdiri dari individu-individu yang telah tersedia dan siap untuk dijadikan sampel (Howit dan Cramer, 2000). Banyaknya SMP Negeri yang ada di Kota Bandung yang dijadikan sampel adalah lima sekolah SMP Negeri dengan siswa terbanyak bersumber dari website http://ppdb.bandung.go.id. Proses perhitungan sampel yang dilakukan ini menggunakan convenience sampling karena peneliti yang menentukan langsung lima sekolah dengan jumlah siswa terbanyak. Dengan mengambil sampel di SMP yang siswanya banyak diharapkan pula bahwa proses screening mendapatkan siswa yang 
menjadi korban bullying pun akan lebih banyak pula.

Terdapat dua kuesioner yang digunakan dalam penelitian ini. Pertama adalah kuesioner untuk screening tindakan bullying yang dialami oleh remaja siswa SMP dan kuesioner mengenai negative automatic thoughts. Kuesioner penapisan atau screening yang digunakan adalah kuesioner untuk menjaring siswa SMP yang menjadi korban bullying yang merupakan bentuk revisi terhadap kuesioner dari Olweus Bully/ Victim Questionnaire (Olweus, 1996 dalam Khasanah, 2014). Pertanyaan-pertanyaan dalam survey ini meliputi berbagai topik yang terkait dengan bullying di sekolah. Topik pertanyaan meliputi prevalensi dari bullying, tipe-tipe bullying, durasi dari kekerasan yang dialami, lokasi terjadinya kekerasan, memberitahukan tindakan kekerasan yang dilakukan siswa-siswi (guru, orang dewasa lain, teman, saudara), dan respon orang lain dalam situasi bullying, misalnya para guru, orang dewasa yang ada di rumah, atau siswa-siswi lain (Losey, 2009 dalam Khasanah, 2014).

Kuesioner yang kedua adalah kuesioner yang dikembangkan oleh Macquire University di Sidney, yang mana di tempat tersebut telah dilakukan penelitian mengenai pikiran-pikiran negatif ini dan kemudian membuatnya ke dalam sebuah instrumen alat ukur berupa kuesioner (Schniering dan Rapee, 2002). Alat ukur ini mulanya digunakan pada remaja yang berdasar pada pernyataan diri atau self-statement yang disebabkan oleh masalah kecemasan, depresi, atau masalahmasalah perilaku lainnya. Para peneliti di sana kemudian mengelompokkan negative automatic thoughts ini ke dalam 4 faktor atau area yang berbeda, yaitu social threat, physical threat, personal failure, dan hostility. Melalui kuesioner ini, peneliti dapat melihat faktor atau area mana yang paling tinggi frekuensi kemunculannya. Artinya, faktor itulah yang paling menunjukkan dampak signifikan yang dialami oleh korban bullying pada pikiranpikiran otomatisnya.

\section{Hasil Penelitian Dan Pembahasan}

Berdasarkan penjelasan sebelumnya mengenai penentuan sampel, ditentukan bahwa siswa yang menjadi sampel berasal dari lima sekolah SMP Negeri dengan siswa terbanyak bersumber dari website http://ppdb.bandung.go.id. Hanya saja pada saat proses permintaan izin, pihak SMPN E Bandung tidak memberikan konfirmasi, sehingga untuk selanjutnya pengambilan data hanya dilakukan di empat SMP saja.

Dari keseluruhan sampel penelitian pada proses screening, dilakukan pengolahan data untuk melihat bagaimana kondisi tingkat bullying yang terjadi di setiap sekolah. Siswa-siswa yang mempunyai frekuensi tindakan bullying yang dialami tergolong tinggi dan sedang akan dijadikan sampel berikutnya untuk melihat seberapa sering munculnya pikiranpikiran negatif melalui kuesioner Children Automatic Thoughts Scale (CATS).

Setelah melakukan screening pada tahap yang telah dijelaskan sebelumnya, maka siswa-siswa yang mengalami tingkat bullying sedang dan tinggi akan dijadikan sampel kembali untuk mengukur frekuensi kemunculan pikiran-pikiran negatif yang bersifat otomatis melalui kuesioner CATS. Secara keseluruhan jumlah siswa yang akan dijadikan sampel pada tahapan CATS disajikan pada tabel 1 .

Dari keseluruhan sampel penelitian pada proses screening, dilakukan pengolahan data untuk melihat bagaimana kondisi tingkat bullying yang dialami. Siswa-siswa yang mempunyai frekuensi tindakan bullying yang dialami tergolong tinggi dan sedang akan dijadikan sampel berikutnya untuk pengambilan data tahap kedua dimana pada tahap ini bermaksud untuk melihat seberapa sering munculnya pikiran-pikiran negatif melalui kuesioner Children Automatic Thoughts Scale (CATS). 
Tabel 1

Rekapitulasi Hasil Screening

\begin{tabular}{cccc}
\hline & $\begin{array}{c}\text { Jumlah } \\
\text { Siswa } \\
\text { Kelas 7 }\end{array}$ & $\begin{array}{c}\text { Jumlah } \\
\text { Siswa } \\
\text { Kelas 8 }\end{array}$ & Total \\
\hline SMP A & 331 & 335 & 666 \\
SMP B & 0 & 118 & 118 \\
SMP C & 68 & 92 & 160 \\
SMP D & 157 & 160 & 317 \\
TOTAL & 556 & 705 & 1261 \\
\hline
\end{tabular}

Setelah melakukan screening pada tahap yang telah dijelaskan sebelumnya, maka siswa-siswa yang mengalami tingkat bullying sedang dan tinggi akan dijadikan sampel kembali untuk mengukur frekuensi kemunculan pikiran-pikiran negatif yang bersifat otomatis melalui kuesioner CATS. Secara keseluruhan jumlah siswa yang akan dijadikan sampel pada tahapan CATS disajikan pada tabel 2 .

Tabel 2

Rekapitulasi Sampel Siswa Berdasarkan Tingkat Bullying

\begin{tabular}{cccccc}
\hline \multirow{2}{*}{ Tingkat } & \multicolumn{5}{c}{ Sekolah } \\
\cline { 2 - 5 } Bullying & SMP & SMP & SMP & SMP & Total \\
& A & B & C & D & \\
\hline TINGGI & 19 & 3 & 15 & 11 & 48 \\
SEDANG & 166 & 35 & 53 & 79 & 333 \\
Total & 185 & 38 & 68 & 90 & 381 \\
\hline
\end{tabular}

Berdasarkan tabel 2 terlihat bahwa seharusnya sebanyak 381 siswa yang akan dijadikan sampel pada tahapan kedua, hanya saja terdapat beberapa kendala diantaranya jadwal para siswa yang tidak sesuai, kegiatan sekolah yang bersamaan dengan jadwal pengambilan data, dan ketidakhadiran siswa yang bersangkutan pada saat pengambilan data. Dengan demikian akhirnya peneliti hanya dapat memperoleh data dari 108 siswa saja. Adapun hasil yang didapat berdasarkan sampel dalam tahapan CATS dapat dilihat pada tabel 3 .
Tabel 3

Rekapitulasi Sampel Siswa Berdasar-kan Kriteria CATS

\begin{tabular}{ccc}
\hline Kriteria CATS & Frekuensi & $\%$ \\
\hline RENDAH & 0 & 0 \\
SEDANG & 99 & 0.91667 \\
TINGGI & 9 & 0.08333 \\
TOTAL & 108 & 1 \\
\hline
\end{tabular}

Berdasarkan tabel 3, terlihat bahwa siswa-siswa dengan tingkat frekuensi tindakan bullying tergolong sedang dan tinggi, mayoritas mempunyai skor CATS dengan kriteria sedang yaitu sebanyak 91.667\%. Dapat dikatakan bahwa, umumnya para remaja yang mengalami tindakan bullying, mengalami frekuensi kemunculan negatif automatic thoughts yang sedang ketika mereka dihadapkan pada situasi bullying atau hal-hal yang diasosiasikan dengan pengalaman bullying yang mereka miliki.

Tabel 4

Tabel Kontingensi antara Kriteria Screening dan Kriteria CATS

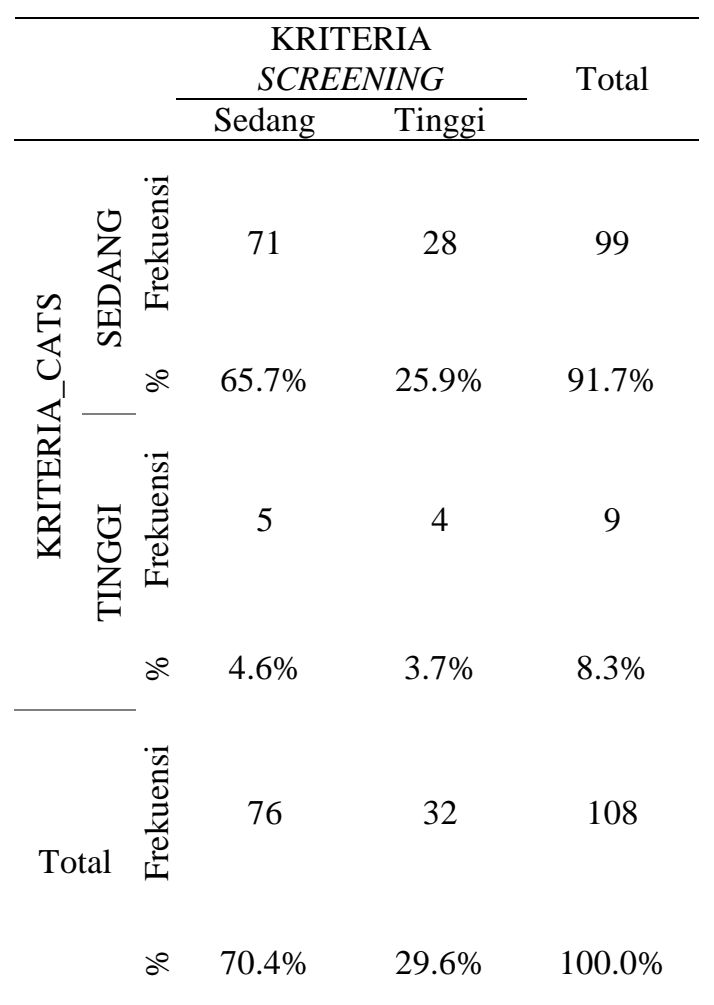




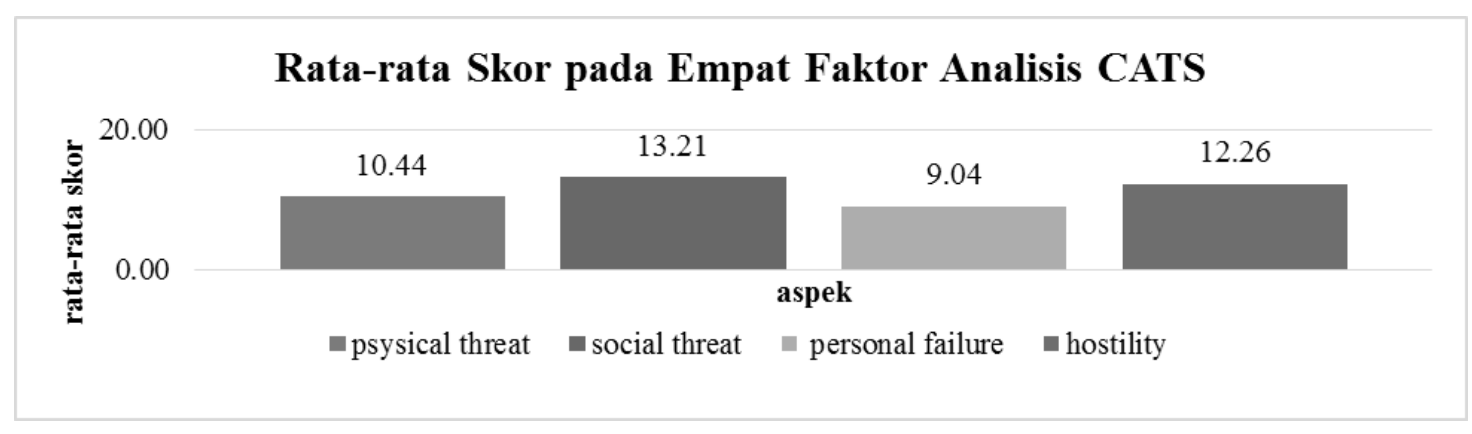

Gambar 1. Rata-rata Skor pada Empat Faktor Analisis CATS

Jika dikaitkan antara kriteria tingkat bullying dan kriteria CATS maka akan didapatkan tabel kontingensi yang tertera pada tabel 4. Berdasarkan tabel 4, terlihat konsistensi antara siswa yang pada tahapan screening masuk pada kriteria sedang dan pada tahapan CATS pun masuk pada kriteria sedang yaitu sebesar $65.74 \%$, sedangkan siswa yang pada tahapan screening masuk pada kriteria tinggi dan pada tahapan CATS masuk pada kriteria sedang yaitu sebesar $25.93 \%$.

Pada gambar 1 tertera hasil rata-rata dari keempat dimensi dalam kuesioner Children Automatic Thoughts Scale (CATS). Keempat dimensi ini disebut sebagai empat faktor yang memunculkan negative automatic thoughts pada anak dan remaja. Faktor-faktor tersebut adalah physical threat, social threat, personal failure, dan hostility (Schniering dan Rapee, 2002). Physical Threat ini mencakup item-item yang berhubungan dengan kondisi fisik, kecelakaan, kematian. Social threat mencakup item-item yang berhubungan dengan perlakuan sosial yang menyebabkan kekhawatiran atau penilaian negatif terhadap lingkungannya. Personal failure mencakup item-item yang berhubungan dengan penilaian diri anak atau remaja terhadap kemampuan dirinya. Sementara, hostility mencakup item-item yang berhubungan dengan nuansa permusuhan dengan orang-orang di sekitar.

Keempat faktor analisis ini menunjukkan faktor mana yang paling besar dan memengaruhi munculnya negative automatic thoughts pada remaja korban bullying. Diambil rata-rata total skor dari setiap kelompok item pada masing-masing faktor analisis dari CATS untuk melihat dimana faktor yang paling memengaruhi sehingga berkontribusi pada tingginya frekuensi kemunculan pikiranpikiran negatif otomatis pada para korban bullying.

Berdasarkan hasil di atas, terlihat bahwa social threat menjadi faktor yang paling tinggi skor rata-ratanya pada 108 responden yang mengisi kuesioner CATS. Kemudian, personal failure menjadi faktor yang paling rendah berkontribusi dalam munculnya pikiran-pikiran negatif pada para korban bullying. Rata-rata skor total untuk faktor ini adalah 9,04. Berdasarkan hasil yang diperoleh di lapangan, terlihat bahwa sebanyak 48 siswa tergolong pada siswa yang mengalami tindakan bullying paling tinggi dari total 1.261 sampel yang terlibat di dalam proses screening. Kemudian, terdapat 333 siswa yang mengalami tindakan bullying dalam frekuensi sedang.

Jika ditinjau secara konsep teori, remaja yang mengalami tindakan bullying yang tinggi, akan mengalami kemunculan pikiran-pikiran negatif yang bersifat otomatis dalam frekuensi yang tinggi pula. Sebab, semakin besar stimulus yang diterima, maka asosiasi negatif akan semakin kuat melekat pada sistem belief remaja. Hal ini kemudian membuat remaja mengembangkan sebuah skema bahwa dunia menjadi tidak aman baginya dan 
sangat berbahaya. Muncul konsep ketidakberdayaan dan kemudian mengontrol sebagian besar kehidupan mereka dan membuat sebuah kekhawatiran muncul secara berlebihan (Wang, 2011).

Sebanyak $8,3 \%$ dari total remaja yang mengalami tindakan bullying, memiliki skema beliefs yang negatif dan sering mengalami ketidakberdayaan dalam kehidupan sehari-harinya. Mereka akan sering merasa cemas apabila dihadapkan pada situasi yang berhubungan dengan tindakan bullying, misalnya bertemu dengan para pelaku, berada di tempat di mana mereka pernah di-bully, atau hal lain yang berkaitan dengan pengalaman yang ia peroleh. Di dalam proses pembentukan beiefs pada para remaja ini, terdapat proses belajar bahwa dunia menjadi tidak lagi ramah dan nyaman baginya. Akibatnya, sebagai remaja yang perlu membentuk jati diri yang kokoh, mereka justru membentuk sebuah konsep ketidakberhargaan diri, ketidakberdayaan, dan kekhawatiran yang sangat besar. Perilakunya dalam kehidupan sehari-hari menjadi tidak sesuai dengan kondisi faktual yang ada. Misalnya, menghindari atau melarikan diri dari masalah, baik itu masalah besar maupun kecil, karena merasa tidak mampu dan tidak berdaya menghadapi kondisi tersebut.

Para remaja korban bullying akan belajar bahwa situasi atau para pelaku bullying adalah ancaman karena pasti kejadian yang sama akan terulang seperti biasanya. Remaja yang mengalami bullying mungkin mengembangkan skema atau beliefs bahwa dunia adalah sesuatu yang tidak aman dan berbahaya dan bullying adalah sesuatu yang di luar kontrol mereka, dimana hal ini mengantarkan pada perasaan tidak berdaya dan kekhawatiran yang berlebihan (Wang, 2011). Hal ini merupakan salah satu bentuk negative automatic thoughts yang muncul pada remaja yang memiliki pengalaman tidak menyenangkan di masa lalu. Muncul pemikiran-pemikiran bernuansa pesimis dan memunculkan rasa tidak nyaman sehingga membuat individu cenderung merasa tidak berdaya menghadapi situasi atau para pelaku bullying.

Pikiran-pikiran negatif yang bersifat otomatis bersifat tidak realistis. Artinya, semakin tinggi frekuensi kemunculan pikiran-pikiran negatif tersebut, maka mereka menilai lingkungan secara tidak realistis. Diantaranya, perasaan-perasaan dari keburukan kita atau ketidakberhargaan, tidak dicintai, kurangnya kepercayaan terhadap diri sendiri atau orang lain, dan kurangnya kontrol terhadap hidup (Beck dkk., 1990; Layden dkk., 1993; Young dan Klosko, 1993; Young dan Behary, 1998, dalam Sanders dan Wills, 1993), dimana hal ini pada dasarnya belum tentu betulbetul ia alami. Karena, hal ini hanya muncul di dalam pemikirannya sendiri dan mereka tidak berdaya untuk mengendalikan aliran deras pikiran-pikiran negatif yang muncul secara otomatis tersebut.

Sementara, terdapat 99 remaja, atau $91,6 \%$ dari total responden yang mengisi CATS, yang mengalami kemunculan pikiran-pikiran negatif yang bersifat otomatis dalam frekuensi sedang. Pada penelitian ini, frekuensi 'sedang' juga dinilai sebagai situasi yang memerlukan perhatian. Sebab, karena kemunculan pikiran-pikiran negatif ini sangat fluktuatif dan dipengaruhi oleh seberapa sering mereka mengalami tindakan bullying, maka peluang naik dan turunnya frekuensi pikiran negatif pun menjadi cukup besar pula.

Apabila ditinjau dari faktor-faktor analisis dari kuesioner CATS, terdapat empat faktor yang berkontribusi dalam kemunculan negative automatic thoughts pada remaja korban bullying, diantaranya physical threat, social threat, personal failure, dan hostility (Schniering dan Rapee, 2002).

Berdasarkan hasil pengambilan data, faktor yang paling tinggi memengaruhi kemunculan negative automatic thoughts adalah social threat. Artinya, dapat dikatakan bahwa social threat menjadi 
faktor yang paling berkontribusi dalam meningkatkan frekuensi kemunculan negative automatic thoughts pada remaja korban bullying. Meski, dapat disampaikan pula bahwa setiap remaja yang mengalami korban bullying tidak selalu dipengaruhi oleh social threat hingga kemunculan pikiran negatif menjadi tinggi. Faktor lainnya pun turut berkontribusi, namun sebarannya menjadi relatif lebih rendah.

Sementara, faktor personal failure menjadi faktor yang paling rendah kontribusinya terhadap kemunculan negative automatic thoughts pada remaja korban bullying. Artinya, hal-hal yang berhubungan dengan penilaian negatif dan persepsi kegagalan atau ketidakberhargaan diri pada mereka yang mengalami bullying, bukan menjadi faktor yang paling tinggi memengaruhi tingginya frekuensi kemunculan negative automatic thoughts. Meskipun pada konsep teori disampaikan bahwa para korban bullying umumnya mengalami dampak psikologis hingga memengaruhi self-esteem atau penilaian diri mereka menjadi negatif (McMannis, 2012).

Subjek yang berada pada skor CATS 'sedang', dinilai bahwa kemampuan reality check-nya masih dapat dikendalikan. Sebab pada dasarnya, pikiran-pikiran negatif ini dapat dikendalikan secara sadar oleh otak kita dan memengaruhi kemampuan kita menilai situasi yang dihadapi. Karena bersifat otomatis, maka ia dapat ditarik ke area pikiran sadar kita dan kemudian dapat kita kendalikan dengan bentuk pemikiran lain yang menjadi tandingan.

Peneliti kemudian membuat analisa dan sesuai dengan yang telah dijelaskan sebelumnya, bahwa frekuensi kemunculan pikiran-pikiran negatif yang bersifat otomatis ini memiliki peluang untuk naik dan turun. Hal ini disebabkan oleh adanya faktor kendali dan identifikasi, sehingga memengaruhi proses spontanitas yang menjadi karakteristik dari Automatic thoughts itu sendiri. Artinya terkadang pada saat kita berusaha untuk mengenali- nya, aliran pikiran-pikiran negatif ini mendominasi sebagian kumpulan pikiran dan membuat kita lebih mempercayainya dibanding bentuk pikiran yang lain. Apabila seorang remaja yang mengalami tindakan bullying, maka pikiran-pikiran negatif yang terasosiasi dengan pengalaman mereka muncul secara spontan. Namun, seperti telah dijelaskan sebelumnya, apabila kita berusaha untuk mengenali automatic thoughts tersebut, pada dasarnya kita tengah mencoba untuk mengendalikannya.

Prinsip yang digunakan adalah perlunya kita mengenali kehadiran negative automatic thoughts dan menolak kebenarannya. Kemudian, barulah mencari alternatif pemikiran untuk mengimbanginya (Beck, 2011), salah satunya dengan menggunakan pikiran-pikiran positif.

Seiring dengan semakin menguatnya pikiran yang lebih positif, pikiran-pikiran ini akan menjadi cara pikir dasar kita dan dominasi NAT dalam pikiran pun akan berangsur-angsur pudar (Wilding dan Milne, 2010).

Peneliti melihat temuan di lapangan pada saat melakukan pengambilan data tahap kedua (CATS), pada beberapa responden mengalami proses jeda yang telah dijelaskan tadi ketika mengisi kuesioner. Pada instruksi telah disampaikan bahwa mereka diminta mengisi sesuai dengan apa yang dipikirkan seketika setelah selesai membaca setiap pernyataan. Karena automatic thoughts bersifat spontan, maka asumsinya, responden akan seketika mengisi sesuai dengan apa yang muncul pertama kali. Sementara, beberapa responden terlihat mengalami jeda ketika menentukan pilihan jawaban.

\section{Simpulan dan Saran}

Hasil proses screening dengan jumlah sampel 1.261 remaja, sebanyak 48 siswa tergolong pada siswa yang mengalami tindakan bullying dan terdapat 333 siswa 
yang mengalami tindakan bullying dalam frekuensi sedang.

Sebanyak $8,3 \%$ dari total remaja yang mengalami tindakan bullying, memiliki skema beliefs yang negatif dan sering mengalami ketidakberdayaan dalam kehidupan sehari-harinya. Artinya siswa yang mengalami tindakan bullying akan sering merasa cemas apabila dihadapkan pada situasi yang berhubungan dengan tindakan bullying.

Sebanyak 99 remaja, atau 91,6\% mengalami kemunculan pikiran-pikiran negatif yang bersifat otomatis (automatic thoughts ) dengan frekuensi sedang. Artinya munculnya pikiran-pikiran negatif sangat fluktuatif dan dipengaruhi oleh seberapa sering mengalami tindakan bullying, Maka peluang naik dan turunnya frekuensi pikiran negatif pun menjadi cukup besar.

Faktor analisis dalam kuesioner CATS yang paling tinggi rata-rata skor totalnya adalah social threat, yaitu sebanyak 13,21. Sementara, sebanyak 9,04 dari total skor adalah personal failure yang merupakan faktor yang paling rendah berkontribusi dalam memunculkan frekuensi negative automatic thoughts pada remaja korban bullying.

Adapun saran yang dapat diajukan berdasarkan hasil penelitian yang telah diperoleh yang meliputi rekomendasi bagi pengembangan penelitian dalam topik bullying pada remaja dan terkait peran lingkungan terhadap penanganan dampak bullying yang diakibatkan oleh kemunculan negative automatic thoughts. Berikut penjelasan saran penelitian tersebut:

\section{Penelitian Selanjutnya}

Pada penelitian ini, jumlah total siswa yang berkontribusi dalam proses pengambilan data tahap kedua masih belum mencakup keseluruhan siswa yang telah berhasil ter-screening pada tahap 1 disebabkan kendala teknis. Oleh sebab itu, pada penelitian berikut-nya, diharapkan kendala teknis seperti jadwal atau durasi pengambilan data, dapat diantisipasi dan disampaikan dengan baik pada pihak sekolah.

Agar dapat memperoleh hasil yang lebih komprehensif, proses pengam-bilan data pada remaja korban bullying dapat dilengkapi dengan melakukan wawancara mengenai kondisi psikis mereka, sehingga dapat memperkaya data.

\section{Aplikasi Praktis}

Hasil penelitian menunjukkan bahwa frekuensi negative automatic thoughts umumnya berada pada tingkat sedang hingga tinggi dan hal ini kemudian dapat memengaruhi kehidupan sehari-hari mereka secara sosial. Oleh karena itu, disarankan agar dapat dilakukan penyusunan program penanganan dalam bentuk pelatihan penggunaan positive selftalk sesuai dengan permasalahan yang dihadapi masing-masing remaja, untuk mereduksi frekuensi kemunculan negative automatic thoughts. Positive self-talk adalah percakapan internal di dalam hati yang berupa pernyataan yang bersifat positif kemudian dilakukan secara berulang-ulang. Kata-kata ini selanjutnya menjadi faktor kognitif yang akan terkondisikan secara otomatis.

Untuk penanganan terkait social threat pada remaja korban bullying, dapat diberikan pelatihan untuk pe-ningkatan keterampilan sosial melalui prinsip modifikasi perilaku. Dapat di-mulai dengan melatih kemampuan menilai situasi, menyusun rencana ke-tika menghadapi situasi sosial, dan me-munculkan dorongan positif untuk da-pat menampilkannya di lingkungan. Hal ini dilakukan agar penilaian terhadap hambatan di lingkungan/ setting sosial (social threat) yang memunculkan pikiran-pikiran negatif, dapat dikurangi. Dengan menggabung-kan penggunaan positive self-talk, maka penanganan akan semakin holistik. 


\section{Daftar Pustaka}

Asri, A.C. (2012). Studi Deskriptif mengenai Profil Kebutuhan pada Pelaku Bullying di SLTP X Bandung (Studi Berdasarkan Teori Kebutuhan Murray), Skripsi Tidak Dipublikasikan, Bandung: UNISBA.

Beck, J. (2011). Cognitive Behavior Therapy: Basics and Beyond, New York: The Guilford Press.

Buxton, D., Potter, M.P., \& Bostic, J.Q. (2013). Coping Strategies for Child Bully-Victims, Pediatric Annals, 42(4), e57-e61.

Howit, D. \& Cramer, D. (2000). First Steps in Research and Statistics: A Practical Workbook for Psychology Students, London: Routledge.

Khasanah, A.N. (2014). Positive Self-Talk Sebagai Intervensi untuk Menurunkan Frekuensi Negative Automatic Thoughts pada Remaja Tingkat Sekolah Menengah Pertama yang menjadi Korban Bullying, Tesis Tidak Dipublikasikan, UNPAD.

McMannis, D. (2012). Middle School Bullying Prevention \& Intervention: An Overview of, San Fransisco: Alliant International University.

McMillan, J. (2006). Research in Education: Evidence-Based Inquiry, Boston: Pearson Education, Inc.

Sanders, D. \& Wills, F. (2003). Counseling for Anxiety Problems: Second Edition, London: Sage Publications.

Saptandari, E.W. \& Adiyanti, M.G. (2013). Mengurangi Bullying melalui Program Pelatihan "Guru Peduli", Jurnal Psikologi, 4(2), 193-210.

Schniering, C. \& Rapee, R. (2002). Development and Validation of a Measure of Children's Automatic Thoughts: the Children Automatic Thoughts Scale, Behaviour Research and Therapy, 40.

Soedjatmiko, Soedjatmiko, Nurhamzah, Waldi, Maureen, Anastasia,
Wiguna, \& Tjhin. (2013). Gambaran Bullying dan Hubungannya dengan Masalah Emosi dan Perilaku pada Anak Sekolah Dasar, Fakultas Kedokteran Universitas Indonesia: Sari Pediatri.

Wang, C. (2011). A Longitudinal Investigation of Peer Victimization, Self-Esteem, Depression, and Anxiety among Adolescents: A Test of Cognitive Diathesis-Stress Theory, Disertation University of Nebraska.

Wilding, C. \& Milne, A. (2010). Cognitive Behavioral Therapy, Canada: McGraw Hill Ryerson Ltd. Diterjemahkan oleh: Fuandy, Ahmad. Jakarta: PT. Indeks. 
Psympathic, Jurnal Ilmiah Psikologi Desember 2017, Vol. 4, No. 2, Hal : 239 - 250 